\title{
ACCeleration of Labour Cost Along With Deceleration of Productivity: How the Slovak Manufacturing Lost THE AdVANTAge OF LOW UNIT LABOUR COST
}

Karol Morvay ${ }^{1}$, Martin Hudcovsk ${ }^{2}$

\begin{abstract}
The recent development in the Slovak economy erased a significant competitive advantage of manufacturing - low labour cost. The paper analyses the driving factors of rising unit labour costs in the manufacturing sector. The paper aims to explain why the unexpectedly rapid loss of traditional competitive advantage took place in the group of V4 countries and why this phenomenon was particularly pronounced in Slovakia. The paper identifies the driving factors that caused a strong increase in labour costs in addition to factors that also caused a slowdown in productivity growth. The decomposition of ULC dynamics has shown that the primary problem in the case of Slovakia is a very significant slowdown in labour productivity growth. Especially, from a marginal perspective, the components of gross value added developed strongly in favour of increasing compensations of employees. The decrease in the working-age population represented a significant driving force of increasing labour cost (wages) along with a halt in productivity growth caused by relatively low investment rate and absence of convergence in capital-to-labour ratio. Such development was identified in all V4 countries; however, the least favourable trend took place in Slovakia.
\end{abstract}

\section{Keywords}

Unit Labour Cost, Slovakia, Labour Productivity, Capital-to-labour

\section{Introduction}

The main inspiration of this paper is the problem in the real economy: Since 2015, significant growth in labour cost accompanied by a slowdown in productivity caused robust growth in unit labour cost in the V4 economies. The tendency was particularly

\footnotetext{
${ }^{1}$ University of Economics in Bratislava, Dolnozemnská cesta 1, 85235 Bratislava, Slovakia, and Institute of Economic Research, Slovak Academy of Sciences, Šancová 56, 81105 Bratislava, Slovakia.

E-mail: karol.morvay@euba.sk.

${ }^{2}$ University of Economics in Bratislava, Dolnozemnská cesta 1, 85235 Bratislava, Slovakia, and Institute of Economic Research, Slovak Academy of Sciences, Šancová 56, 81105 Bratislava, Slovakia.

E-mail: martin.hudcovsky@savba.sk.
} 
pronounced in Slovakia. Thus, the traditional factor of competitiveness has been eliminated in the manufacturing sector. For a long time, a warning about the loss of the traditional competitive advantage of the Slovak economy in the form of lower unit labour costs (ULC) has been discussed. In recent years, this expectation took place surprisingly quickly. Situation seemingly hard to imagine before has become a reality: ULC in Slovak manufacturing are suddenly higher than in the more developed EU economies. Such a development has been so far unprecedented and represents a serious break in development trends. On one hand, the workforce is becoming scarce (after decades of surplus) and relatively more expensive; on the other hand, the former leader in productivity growth is stagnating. That requires the interpretation and identification of the causes taking place in the background. The aim is to explain why there was an unexpectedly rapid loss of this traditional competitive advantage in the group of V4 countries and why this phenomenon was particularly pronounced in Slovakia. In this paper, we address the causes of this phenomenon: both a significant increase in labour cost and a slowdown in productivity growth. The paper first provides an overview of the overall picture of the turning point in the development of ULC in an international comparison. Then, it separately deals with problems on the labour cost side and problems on the productivity side. Subsequently, the situation with increasing labour cost growth and weaker productivity growth remerge and explain that out of these two problems, the more fundamental problem is the slowdown in labour productivity.

\section{Literature Review}

Since 2015, the analysis of this problem is strongly represented in the available literature. Żuk et al. (2018) pointed out the fact that productivity ceases to be a driving force for growth. Authors consider the main reason for such development to be a slowdown in investment activity in Central and Eastern Europe as well as in the weak performance of research and development. The moderation of investment dynamics has led to a convergence freeze in terms of the capital-to-labour ratio, as demonstrated by Morvay and Hudcovský (2018). The absence of convergence in the level of capital equipment may be one of the main barriers to catching up with the productivity levels of advanced economies. Lábaj (2018) drew attention to the long-term and relatively inefficient allocation of labour in the manufacturing sector in Slovakia - the inefficient allocation of labour hindered any significant productivity growth. At the same time, the factors that keep the share of wages in value-added have subsided (as identified by Stockhammer, 2013). The wages began to play a much stronger role in the development of economic growth (there was a case of "wage-driven growth" developed by Stockhammer and Onaran, 2012). However, the proposals of some economic currents on the need to reduce the share of wages in total value added can be considered a dead-end (Storm and Naastepad 2015). A converging economy like Slovakia urgently needs to experience a wage increase, without which convergence efforts would be meaningless. Countries in Central Europe have long achieved a lower share of wages in value added. Galgóczi (2017) argues that the designation as a lowcost economy effectively prevents the further development of the region towards more sophisticated production. Already mentioned papers have provided valuable insights into 
the problem of productivity stagnation, as well as to the causes and consequences of increasing/decreasing the share of labour cost in the economic output. However, these papers have not yet been able to interpret the problem of the low ULC benefit loss in the economies of Central and Eastern Europe. They have arisen as a result of a slowdown in productivity growth along with continued growth in labour cost.

\section{Overview: Breakthrough in Labour Cost and Productivity Trends}

We pay special attention to the manufacturing sector. We assume that it is the sector where ULC has played a significant role in determining international competitiveness (manufacturing goods are among the most internationally tradable).

\section{Chart 1: Unit Labour Cost in Manufacturing Sector (V4 and EU 15 average)}

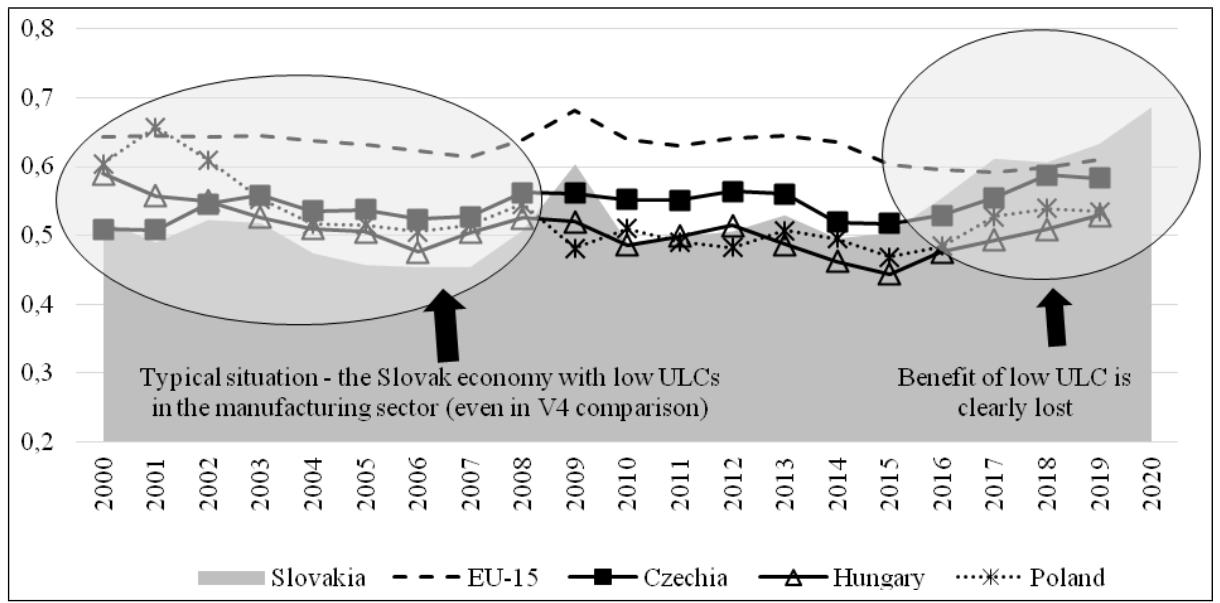

Notes: Calculated as the ratio of the average compensation of employees to labour productivity. Labour productivity is expressed as value-added per worker.

Source: Eurostat database, author's calculations and design

The typical situation in Slovakia where ULC are significantly below the level of the EU-15 average (as well as the level of other V4 economies) has been reversed - see Chart 1. Unit labour cost in the Slovak manufacturing sector has already exceeded the EU-15 level (traditionally the more developed part of the EU). The traditional, albeit already obsolete factor of the competitiveness of Slovak manufacturing, was eliminated (in line with expectations, but still surprisingly fast).

UNC is calculated as the ratio of the average compensation of employees and labour productivity.

$$
U L C=\frac{\text { average compenstation of employee }}{\text { labour productivity }}=\frac{\frac{\text { compensation of employees }}{\text { no. of employees }}}{\frac{\text { gross value added }}{\text { total employment }}}
$$


Notes:

The number of employees and total employment according to the national accounts methodology (domestic concept).

The fraction is usually simplified to the form of compensation of employees / gross value added. It is assumed that the number of employees in the numerator is approximately equal to the number of total employment in the denominator. However, it "fits" only approximately; the number of employed $=$ employees + self-employed. Therefore, some distortion must be taken into account with such fraction adjustment.

In 2020, the economic depression exacerbated the problem; however, it is not its root cause. The sharp increase of ULC in the Slovak manufacturing sector was caused by the continuing growth of the average compensation of employees (even during the economic depression) and the steady decline in labour productivity. The process of ULC rise observed for several years has thus gained further dynamism. ${ }^{3}$

The above ULC formula in the form of a fraction provides an insight into the extent to which the problem is in the numerator of the fraction (in the development of the average compensation of employees) and to what extent it is in the denominator (in the development of labour productivity). Chart 2 provides an overview of the development of ULC determinants - the development of the numerator and denominator of the fraction in the V4 countries. Both determinants - average compensation of employees and labour productivity - slowed down in catching up with the EU-15 level in the period after the economic depression (2009). In all these countries, the flattening of the curves can be seen after 2008, in some cases, the values have even fallen. However, the breakthrough since 2015 (especially in Slovakia and Czechia) is interesting (highlighted in the charts). The tendency to catch up with the average compensation of EU-15 employees has resumed but catching up with the EU-15 labour productivity has remained weak. This moment is the most pronounced in the Slovak economy: while the ratio of compensation of employees to the EU-15 level reaches record high numbers, the productivity-to-EU-15 ratio is approximately at the same level as in 2008! Slovak manufacturing sector lost the advantage of lower ULC not only over the EU-15 but also over the former transforming V4 economies.

\footnotetext{
${ }^{3}$ The data for Slovakia in 2020 could not be compared with the EU-15 average yet (due to missing data from some countries at the time of preparing this paper). However, based on trends from previous years, we assume a higher level in Slovakia.
} 
Chart 2: Development of Determinants of Unit Labour Cost in Manufacturing: Average Compensation of Employees and Labour Productivity (country level compared to EU-15, EU-15 = 100)

a) Slovakia

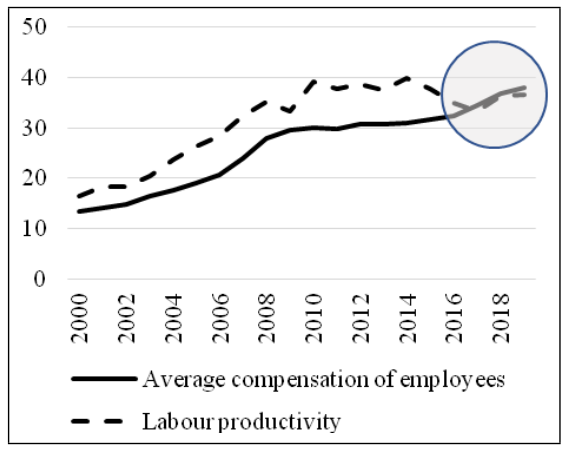

c) Hungary

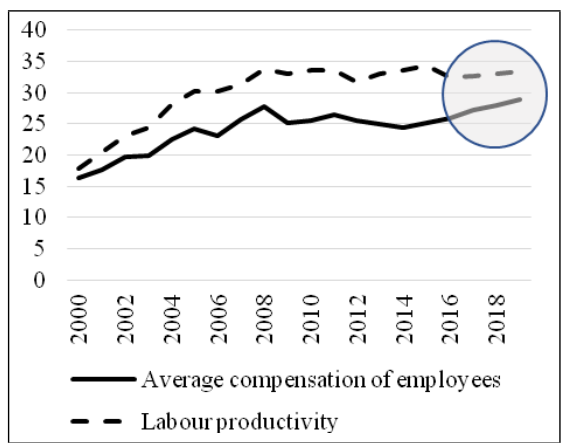

b) Czechia

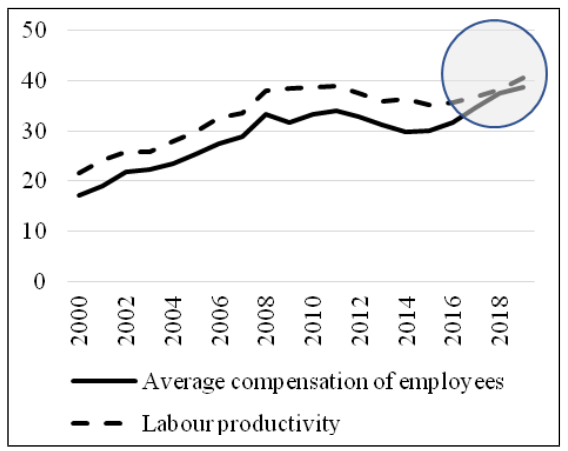

d) Poland

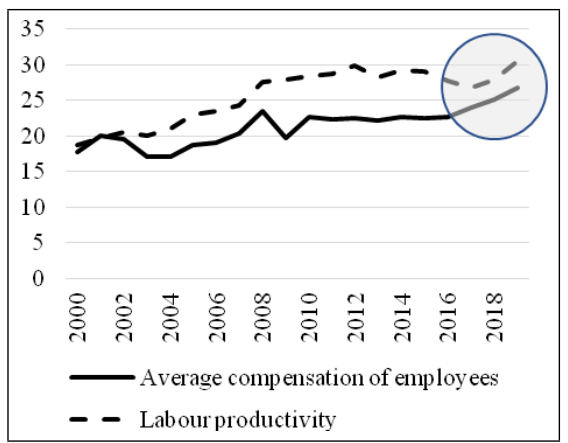

Notes: Labour productivity is expressed as value-added per worker. Calculated in current prices in EUR.

Source: Eurostat database, author's calculations and design (2021)

\section{Rapidly increasing fraction numerator}

The rapid growth of the fraction numerator - the average compensation of employees is related to the rapid increase in the scarcity of the workforce. The demographic factor contributed significantly to this growing scarcity of the labour force: at a time of record growth in demand for labour in Slovakia, the working-age population had fallen sharply (Chart 3). The situation is very similar in other V4 economies. Since 2014, the growth in the number of total employment was accompanied by a decline in the number of the working-age population. The outcome could not be other than a sharp decline in the unemployment rate $^{4}$, rising wages (including labour costs), and pressure to open up to labour immigration.

\footnotetext{
${ }^{4}$ In the case of Slovakia, where the initial unemployment rate was high.
} 
Chart 3: Overlapping Growth in Labour Demand and Decrease in Supply in the V4 Countries (change in the number of employed and the number of the working-age population in 2014-2019,

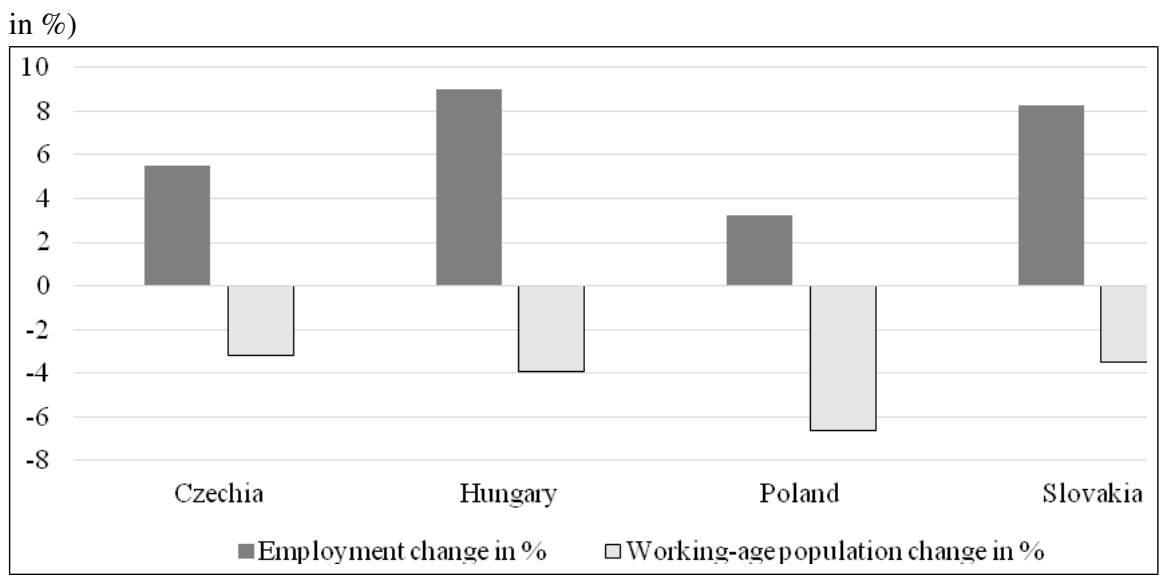

Source: Eurostat database, author's calculations and design (2021)

In this situation, the volume of wages (more precisely, compensation of employees; these are wages and salaries together with social contributions paid to social security funds) grew faster than the value-added created or as GDP. Therefore, profits were crowded out; the wage-to-profit ratio deviated very significantly in favour of wages. That is the opposite of the trend seen before the financial crisis and the 2009 depression (Chart 4).

In the period of significant economic growth 2000-2007, profits (net operating surpluses) strengthened their position at the expense of compensation of employees. In the V4 group, this is best observed in Slovakia. Moreover, in the later growth phase, the exact opposite happened. Again, in the most significant form in Slovakia (see Charts 4a, 4b).

Chart 4: Mutual "Crowding Out" of Profits and Wages: The Ratio of Net Operating Surplus ("Profit") to Compensation of Employees

a) 2000-2007

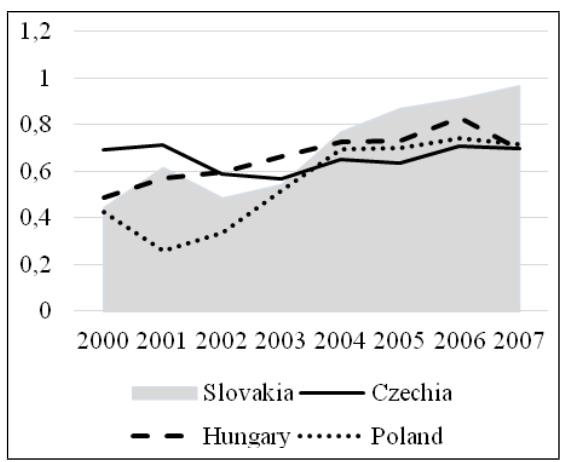

b) 2012-2019

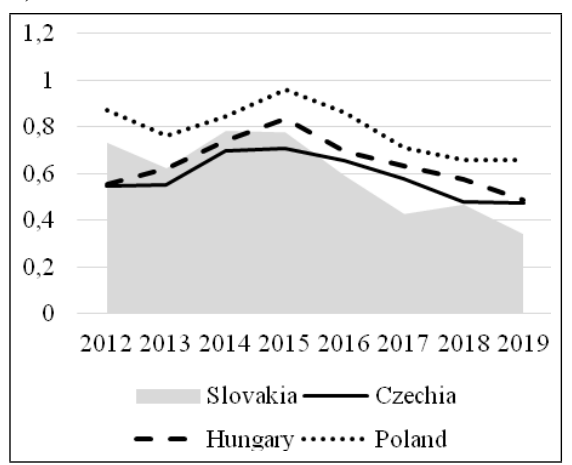

Notes: Calculated from data in current prices in EUR, for the manufacturing sector. Source: Eurostat database, author's calculations and design (2021) 
The aforementioned phenomenon of crowding out profits stands out more significantly from a dynamic point of view: In Table 1, we present a decomposition of 100 EUR of additional generated production:

* In 2001-2007, from 100 EUR of additional production created in Slovak manufacturing, only 7.5 EUR were used for additional compensation of employees; in 2014-2019, it was already 20.6 EUR.

* In 2001-2007, from 100 EUR of additional generated production, there was 10 EUR of additional net operating surplus ("profit"). However, in 2014-2019, the increase in production by 100 EUR was accompanied by a decrease of profits by 2.8 EUR (the decrease of profit was experienced only in Slovakia among the V4 countries).

* It is not surprising that employers perceived such a tendency as a problem. On top of that, the increase in labour cost was also supported by the government administrative measures (the well-known problem of "surcharges" or a sharp increase in the minimum wage).

Table 1: Decomposition of 100 EUR of Additional Production in Manufacturing

\begin{tabular}{|l|c|c|}
\hline \multicolumn{3}{|c|}{$\begin{array}{c}\text { The } 100 \text { EUR of marginal manufacturing production in V4 countries produced the } \\
\text { following marginal revenues (components of gross value added) }\end{array}$} \\
\hline Total Additional Gross Value Added & $2001-2007$ & $2014-2019$ \\
\hline Czechia & 22.6 & 30.9 \\
Hungary & 23.3 & 25.5 \\
Poland & 22.0 & 32.2 \\
Slovakia & 20.6 & 22.9 \\
\hline of which: & \multicolumn{3}{|c|}{} \\
\hline Compensation of Employees & $2001-2007$ & $2014-2019$ \\
\hline Czechia & 11.4 & 18.6 \\
Hungary & 9.8 & 16.0 \\
Poland & 6.3 & 18.1 \\
Slovakia & 7.5 & 20.6 \\
\hline Net Operating Surplus (i.e. Profit) & $2001-2007$ & $2014-2019$ \\
\hline Czechia & 7.7 & 6.0 \\
Hungary & 9.0 & 3.2 \\
Poland & 13.8 & 8.4 \\
Slovakia & 10.0 & -2.8 \\
\hline
\end{tabular}

Notes: Calculated from data in current prices.

Source: Eurostat database, author's calculations (2021)

The indicated phenomenon becomes a real problem only when it is associated with an unsatisfactory development of labour productivity. The increase in labour costs alone would not necessarily be a worrying phenomenon. At this point, we pay the attention to the denominator of the fraction. 


\section{... and its Decelerated Fraction Denominator}

Labour productivity in the denominator of the ULC formula has lost its momentum in the last decade. The dramatic slowdown in productivity growth is visible when comparing two equally long periods before and after the 2009 financial crisis (see Chart 5). In the earlier period, the Slovak economy had the position of a leader in the growth of labour productivity. Later, in the period after 2014, the country has lost this position. In addition, the slowdown in labour productivity growth in the V4 group was most pronounced in Slovakia.

Productivity drivers from the earlier stages (before 2009), have largely disappeared: FDI inflows and associated technology inflows have weakened, investment rates have fallen (investment to GDP share), demand patterns have changed (in favour of goods produced with lower productivity) and others.

It has already been mentioned that during the currently ending economic depression, productivity developed unfavourably and the problem deepened even further. The reason was that during a significant decline in the output of the economy, the effort to preserve as much employment as possible by government measures directly influenced productivity. Therefore, a drop in output with a less significant drop in employment necessarily means a drop in productivity - but it can be short-lived.

\section{Chart 5: Labour Productivity Changes in V4 Countries}

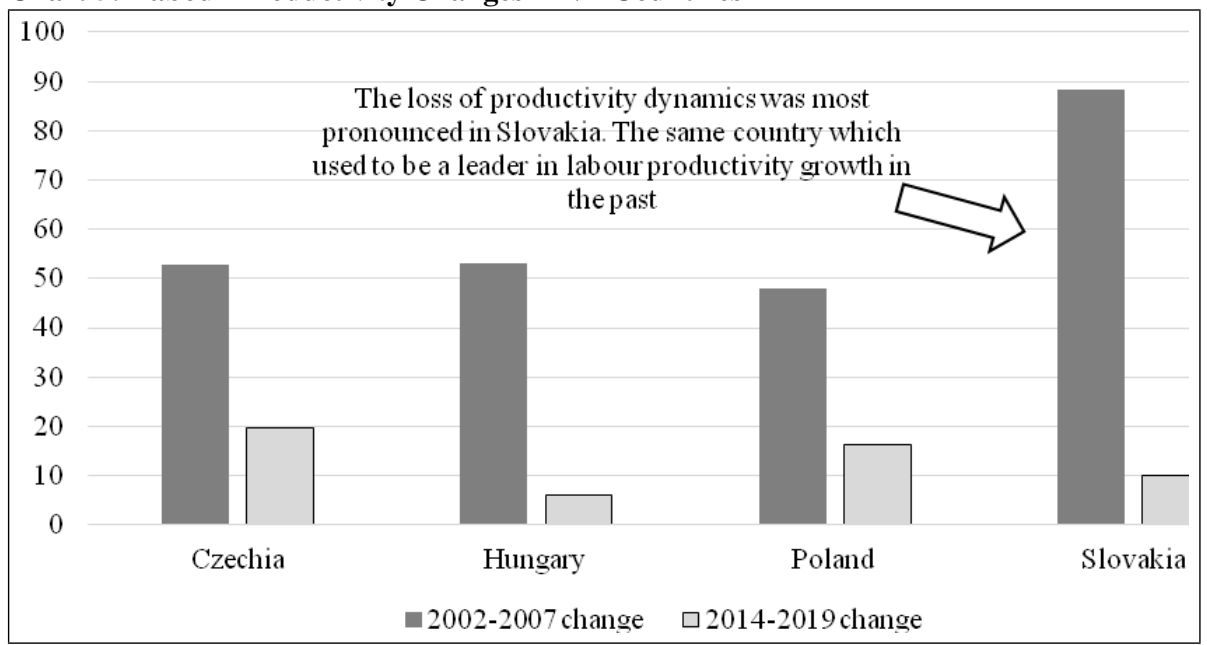

Notes: Calculated from data in constant prices. Productivity is expressed as gross value added per worker.

Source: Eurostat database, author's calculations and design (2021)

We assume that the slowdown in labour productivity growth in Slovakia is related (apart from many structural changes ${ }^{5}$ ) to a decline in investment dynamics. Similar to Żuk et

\footnotetext{
${ }^{5}$ One such structural change is the relocation of much of the output to sectors where productivity is traditionally
} lower. This is related to a change in the structure of demand. For more see Morvay (2020). 
al. (2018), we consider the decrease in the investment rate and the interruption of the catching-up of developed countries in the level of labour-to-capital ratio (Morvay and Hudcovský, 2018) as a factor slowing down productivity growth.

This is one of the manifestations of the fact that the original drivers of productivity growth and real convergence are being exhausted (as also pointed out by the European Commission, 2019). In Chart 6, the large difference in the case of Slovakia may be seen in the level of investment in the manufacturing sector between the two development phases. The already mentioned Slovak leadership in productivity growth in the earlier phase (until 2007) was associated with an exceptionally high level of investment. In the later phase (since 2013), the extensive effect of investment eased - the investment rate in Slovakia fell by almost a third of the earlier level. The achieved level (26.8\%) cannot be automatically described as low (it is similar to the level in Czechia, lower than in Ireland and higher than in Germany). Nevertheless, it is significantly lower than the one in which the Slovak manufacturing was able to achieve strong productivity growth.

Chart 6: Investment Rate in Manufacturing Sector

(Gross Fixed Capital Formation / Gross Value Added, in \%)

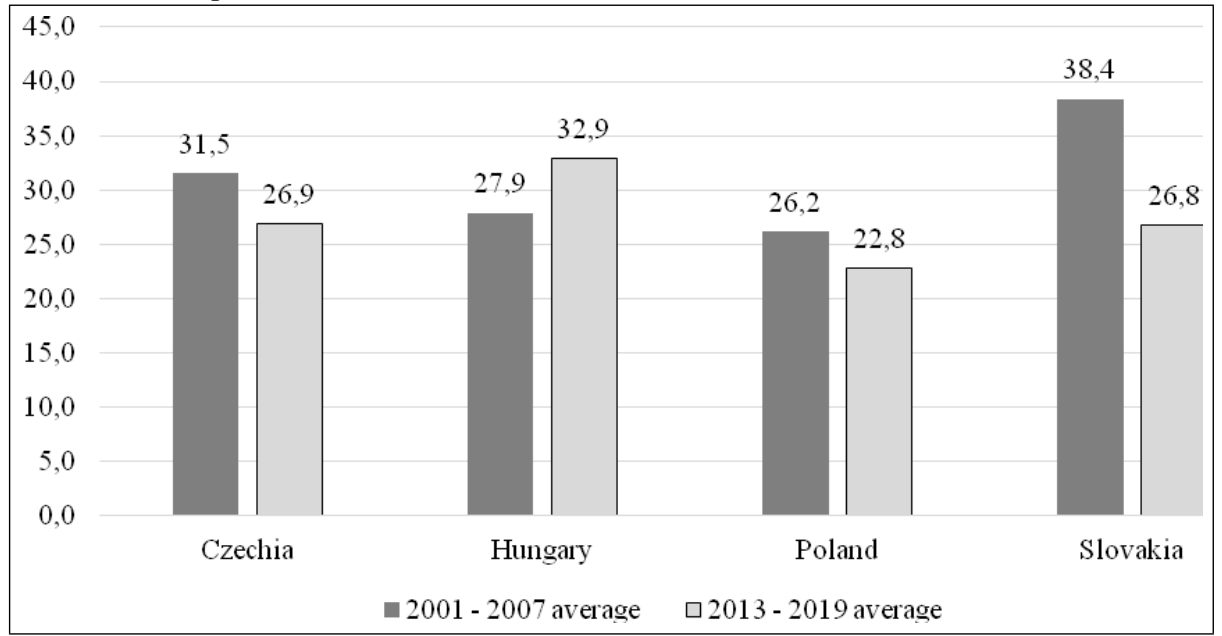

Notes: Calculated from data in current prices.

Source: Eurostat database, author's calculations (2021)

The limitation of investment dynamics is reflected in the less favourable development of the capital-to-labour ratio. Increasing the capital-to-labour ratio is a prerequisite for catching up with the labour productivity of developed economies. In addition, the level of capital-to-labour also changes the nature of their job positions ${ }^{6}$. To evaluate this problem, we employ data on the stock of fixed assets by sectors of the economy. The volume of fixed assets is divided by the number of employees expressing the level of capital-to-labour. We

${ }^{6}$ More on the topic of capital-to-labour development in CEE countries and its effects see Morvay and Hudcovský (2018). 
display the level of capital-to-labour in Slovakia compared to the level of the average of the three EU countries with the highest values of this indicator (Chart 7). We refer to this group of countries as TOP3 and it consists of Belgium, Denmark and the Netherlands.

At the beginning of the observed period (the year 2000, the first available data for Slovak manufacturing), a manifestation of undercapitalisation can be seen: the capital-to-labour ratio was at the level of $28 \%$ of the TOP 3 group. The development of the indicator had two significantly different phases: A significantly rising curve until 2009 indicates a catching up with the level of capital-to-ratio of more advanced economies. At the peak, the ratio reached a level of approximately $42 \%$ of the TOP3 level. Subsequently, however, comes the phase in which Slovakia ceases to catch up with the level in the TOP3 - there is even a departure from this level. The convergence process in this indicator has stalled (or even reversed). That is a limiting factor in labour productivity levels convergence.

\section{Chart 7: Capital-to-labour In Slovakia Compared to TOP3}

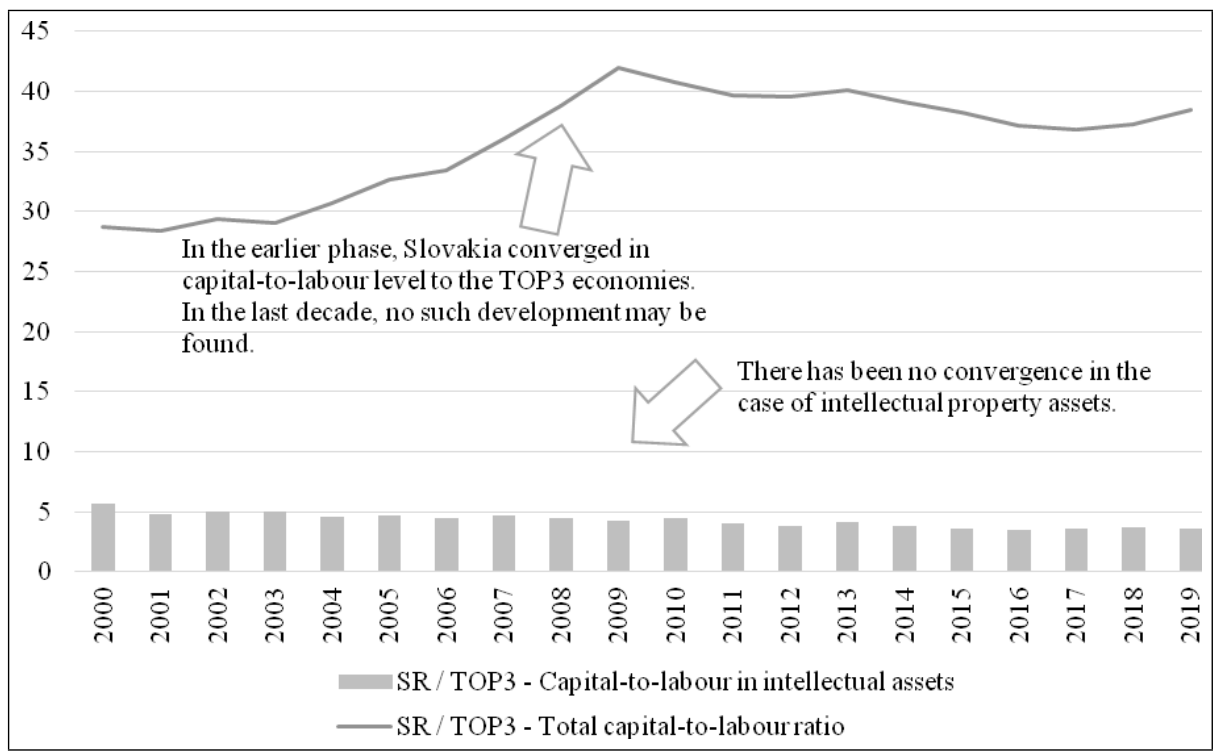

Source: Eurostat database, author's calculations (2021)

Notes:

Data for the manufacturing sector. TOP3 is a trio of developed European economies with the highest level of capital-to-labour ratio (Belgium, Denmark and the Netherlands).

The Capital-to-labour ratio is calculated as the stock of gross fixed assets divided by the number of employees. The number of employees according to national accounts. The values for Slovakia are compared to the levels in the TOP3 group.

Another limiting factor for productivity growth at the level of manufacturing sector may be a significant segmentation of enterprises. Significant segmentation of companies (to those with favourable and unfavourable productivity developments) could deepen the examined problem. In the next step, we deal with differences according to the size of enterprises. 
The differences between the size segments of enterprises in Slovakia have deepened: The productivity growth of the entire sector is significantly driven by the largest enterprises (over 250 employees). In all other size segments, the growth rate of labour productivity was below average (see Chart 8). Even, the productivity in the small business segments in Slovakia decreased. The development in Slovakia is specific in this respect: In other V4 countries, there was no decrease in the productivity of small enterprises and the dynamics of productivity was more balanced across the segments of enterprises (see Morvay, 2020). Therefore, the results mean in terms of Slovak perspective following:

* A higher degree of dependence on labour productivity of a relatively small segment of the largest enterprises.

* In Slovakia, there is insufficient diffusion of high productivity from the largest enterprises to smaller ones.

* The most significant differentiation in the development of productivity according to the size segments of enterprises is in Slovakia among all V4 group countries (Morvay, 2020).

In Slovak manufacturing, the two large segments continue to be separated from each other: a narrow segment of large enterprises with high and strongly growing productivity and a segment of small and medium-sized enterprises that does not reach the top parameters. Only the segment of large enterprises exceeds the average values for the entire manufacturing sector. All categories of small and medium-sized enterprises are at belowaverage levels (Chart 8). The advance of large enterprises over small ones in productivity is a natural phenomenon. However, the decline in the productivity of small and the deepening of the lag of all categories against large ones is a problem.

Chart 8: Labour Productivity Dynamics in Manufacturing by Size Categories of Enterprises (change in \%)

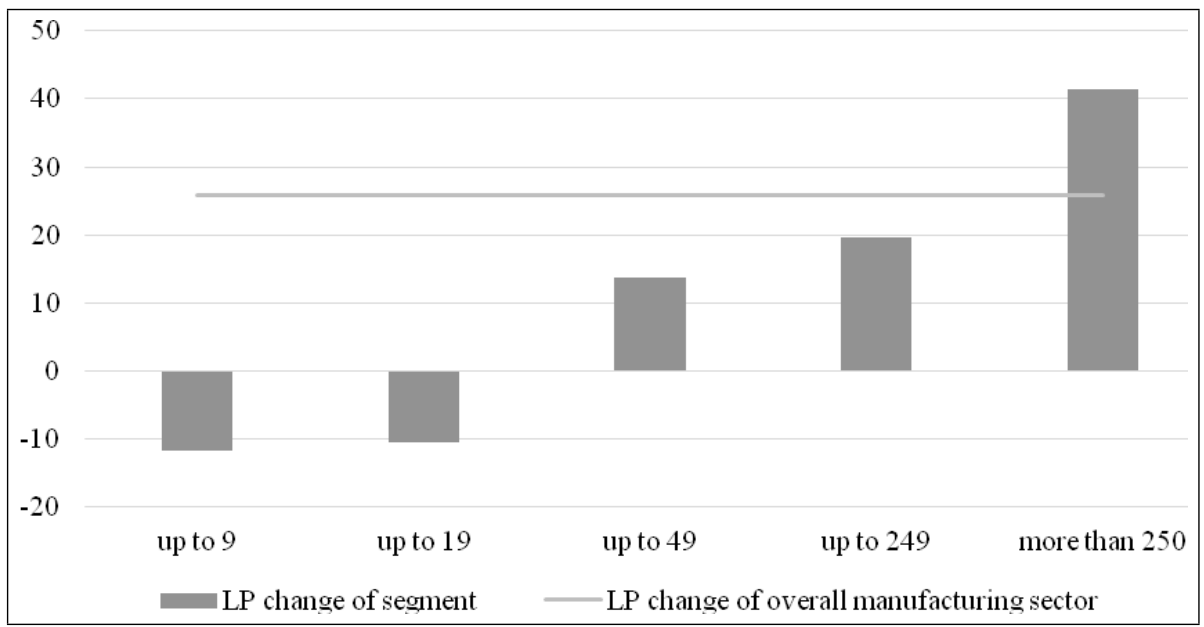

Notes: Size categories based on the number of employees.

Source: Eurostat database, author's calculations (2021) 


\section{Merging Two Factors into One Problem}

After a separate examination of the problems in the numerator and denominator of the ULC fraction, we reconnect the image. Next, we decompose the ULC dynamics index into two components. For easier interpretation, we adjust the ULC formula by converting the fraction mentioned above into a product (we adjust the denominator of the fraction to its inverse value). Therefore, we will use the product of the average compensation of employees and labour intensity. In this way, the ULC change index can be decomposed into the product of two indices. The results of this decomposition are shown in Table 2.

$$
\begin{aligned}
& \text { Index of ULC change }= \\
& =\text { Index of change in average compensation of employee } * \frac{1}{\text { Index of change in labour productivity }}
\end{aligned}
$$

or

$$
\begin{aligned}
& \text { Index of ULC change }= \\
& =\text { Index of change in average compensation of employee } * \text { Index of change in labour intensity }{ }^{7}
\end{aligned}
$$

Table 2: Decomposition of Rate of ULC Change in Manufacturing (index of change for 2014-2019)

\begin{tabular}{|l|c|c|c|}
\hline Country / Group & ULC Change & $\begin{array}{c}\text { Change in Average } \\
\text { Compensation of Employees }\end{array}$ & $\begin{array}{c}\text { Change in Labour Intensity } \\
\text { (Inverse of Productivity) }\end{array}$ \\
\hline EU-15 & 0.960 & 1.078 & 0.890 \\
Czechia & 1.124 & 1.406 & 0.800 \\
Hungary & 1.144 & 1.275 & 0.897 \\
Poland & 1.079 & 1.268 & 0.851 \\
Slovakia & 1.278 & 1.318 & 0.970 \\
\hline
\end{tabular}

Source: Eurostat database, author's calculations (2021)

The results of decomposition in Table 2 display that the highest growth rate of ULC was experienced in Slovakia (when compared in the V4 group and to the EU-15 average). The highest growth index of ULC in Slovakia is thus given by the product of:

* a relatively high index of change in the compensation of employees (second highest after Czechia and significantly higher than in the EU-15), and

* the highest index of change in labour intensity. The highest index of change in labour intensity (although below 1) means the smallest decrease in labour intensity among compared countries. Moreover, since it is the inverse of labour productivity - the smallest decline in labour intensity $=$ the smallest increase in labour productivity.

\footnotetext{
${ }^{7}$ The inverse of labour productivity is labour intensity. It demonstrates what volume of labour is needed per unit of output.
} 


\section{Conclusion}

Slovakia is dealing with relatively strong growth in compensation of employees along with the weakest growth in labour productivity in a given group of economies. Given the past development, this is an unusual constellation for the Slovak economy. Low ULC was during past decades one of the decisive factors for FDI allocations. However, the loss of a traditional competitive advantage in the form of low ULC may not be a serious problem if the economy is already building on other competitive advantages. In addition, the economic depression that exacerbated (but did not cause!) this problem also provided some tips for developing competitiveness factors in the future. These are related to innovations that enable companies to operate relatively reliably even in such shocks as they are currently overcoming. The reliance on traditional competitive factors as low ULC is no longer an option for Slovakia and the need to find a new competitive advantage is a matter of utmost urgency.

\section{Acknowledgements}

This paper is a part of research project VEGA 1/0716/19 (50\%) and VEGA 2/0097/19 $(50 \%)$.

\section{References}

European Commission. (2019). Country Report Slovakia 2019. Communication from the Commission to the European Parliament, the European Council, the European Central Bank and the Eurogroup. Retrieved from https://ec.europa.eu/info/sites/info/files/file_import/2019-european-semester-country-report-slovakia_en_0.pdf.

Galgóczi, B. (2017). Why central and eastern Europe needs a pay rise. ETUI Research Paper-Working paper. Retrieved from https://www.pramprof.lt/images/publikacijos/WP2017-01-payrise-HD-webversionfinale.pdf.

Lábaj, M. (2018). (Ne)efektívne využívanie výrobných faktorov a rozdiely v produktivite práce v rámci spracovatel'ského priemyslu na Slovensku. In: Monitor hospodárskej politiky, 2, jún. ISSN: 2453-9287. https://nhf.euba.sk/www_write/files/veda-a-vyskum/casopisy/ monitor-hospodarskej-politiky/MHP_06_18_final.pdf.

Morvay, K. (2020). Slovenská ekonomika na ceste od nedostatku práce k nedostatku jej produktivity. Bratislava : Vydavatel'stvo EKONÓM. ISBN 978-80-225-4765-9.

Morvay, K., Hudcovský, M. (2018). Overcoming of Lag in the Capital to Labor Ratio in the Slovak Economy. In Ekonomický časopis, 66, 8, 838-851. ISSN 0013-3035.

Stockhammer, E. (2013). Why have wage shares fallen? A panel analysis of the determinants of functional income distribution. International Labour Office, Geneva. Retrieved from http://www.ilo.org/wcmsp5/groups/public/---ed_protect/---protrav/---travail/documents/publication/wcms_202352.pdf.

Stockhammer, E. and Onaran, Ö. (2012). Wage-led growth: Theory, Evidence, Policy. Political Economy Research Institute, University of Massachusets Amherst. Working Paper Series, No. 300. Retrieved from https://www.peri.umass.edu/media/k2/attachments/WP300.pdf. 
Storm, S., Naastepad, C. W. (2015). Europe's Hunger Games: income distribution, cost competitiveness and crisis. Cambridge Journal of Economics, 39(3), 959-986. Retrieved from https://www.networkideas.org/wp-content/uploads/2016/08/Hunger_Games.pdf.

Żuk, P., Polgar, E. K., Savelin, L., Diaz del Hoyo, J. L., Konig, P. (2018). Real convergence in central, eastern and south-eastern Europe. ECB Economic Bulletin Article. Retrieved from https://www.ecb.europa.eu/pub/pdf/other/ecb.ebart201803_01.en.pdf. 